\title{
Efficacy of Kampo Formula Tokishigyakukagoshuyushokyoto for Cold Syndrome Evaluated with a Novel Clinical Method using a Patient-based Questionnaire Database
}

\author{
Yoko KIMURA $^{\mathrm{a}} \quad$ Akira TANAKA $^{\mathrm{b}}$ Hiroshi SATO $^{\mathrm{a}}$ \\ a Institute of Oriental Medicine, Tokyo Women's Medical University, School of Medicine, 1-21-8 Tabata, Kita- \\ ku, Tokyo 114-0014, Japan \\ b Department of Surgery, Tokai University School of Medicine, 143 Shimokasuya, Isehara, Kanagawa 259-1193, \\ Japan
}

患者自身による自覚症状の評価システムを用いた

冷え症に詨する当州四逆加呉荣葫生姜湯の有効性について

木村 容子 ${ }^{\mathrm{a}}$ 田中 彰 $\mathrm{b}$ 佐藤 弘 ${ }^{\mathrm{a}}$

a 東京女子医科大学東洋医学研究所，東京， $=114-0014$ 北区田端1-21-8

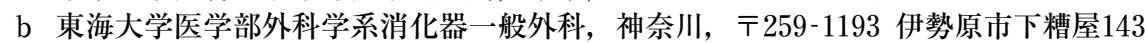

\begin{abstract}
Objectives : Persistent coldness is a common complaint for which Kampo, traditional Japanese herbal medicine, is often tried, because there is no definition or objective measure of subjective coldness in Western medicine. The aim of this study was to evaluate the efficacy of a common Kampo agent, tokishigyakukagoshuyushokyoto, and to identify key symptoms that would predict positive treatment outcomes for coldness.
\end{abstract}

Design : A retrospective cohort study.

Setting : 181 patients who complained of coldness without any organic abnormalities self-surveyed their health using a Kampo questionnaire database system on their first visit. Another 28 patients were assigned to verify the discriminatory predictability of treatment efficacy.

Interventions : Patients were treated with extract product, 7.5 grams a day for a month.

Outcome measures : Treatment efficacy as a binary response.

Results : Frequency and severity scales ( 0 to 4 ) for coldness decreased from $3.2 \pm 0.7$ to $2.1 \pm 0.1$ ( $p<$ $0.01)$ and from $3.1 \pm 0.7$ to $2.2 \pm 0.9(p<0.01)$, respectively. Improvements in both frequency and severity of coldness were observed in $74.0 \%$ of patients. The status of tenderness in the iliac region, without upset stomach or depression, was obtained as an appropriate model for the prediction of treatment effect, and its discriminatory predictability was calculated as $84.4 \%$. The predictive accuracy of the model was validated with $82.1 \%$ for the 28 new patients.

Conclusions : Coldness susceptible to tokishigyakukagoshuyushokyoto was very frequently accompanied by tenderness in iliac region, without upset stomach or depression.

Key words : cold syndrome/coldness, tokishigyakukagoshuyushokyoto, tenderness in the iliac region, upset stomach, depression

要旨

目的：当帰四逆加吳茱蒱生姜湯が有効な冷え症のタイプを検討した。

研究デザイン：後ろ向きコホート研究。

対象：冷え症患者187名を対象とし，初診時に自覚症状をデータベースに登録した。さらに，外的妥当性を新規28 名で評価した。

介入：エキス顆粒7. $5 \mathrm{~g} /$ 日服用 1 カ月後に評価。

評価項目 : 治療効果の有無。

結果 : 冷えは74\%の患者で改善し，頻度および程度 $(0-4)$ は各々3.2 \pm 0.7 か52.1 $0.1(p<0.01), 3.1$ \pm 0.7 か $2.2 \pm 0.9(p<0.01)$ に減少した。治療効果予測の最適モデルとして, 胃もたれおよび抑うつを伴わな い腸骨窩圧痛の有無が選ばれ，判別予測率は84.4\%であった。このモデルを別の28名の患者で検証したところ，予 
測精度は82.1\%であった。

結論：胃もたれや抑うつ感がみられず, 腹診にて腸骨窩圧痛が認められる冷えの患者で, 当帰四逆加吳䒩䤶生姜 湯が有効である可能性が示唆された。

キーワード : 冷え症, 当帰四逆加吳茱膜生姜湯, 腸骨窩圧痛, 胃もたれ, 抑うつ

\section{Introduction}

We often encounter patients complaining of persistent and intolerable "coldness" (chilly sensation) in their bodies, fingertips and toes in a heated room in winter, or in an air-conditioned room even in summer. This unusual feeling of coldness, which is more often observed in women than in men, is called "hi-e-sho" (cold syndrome) in Japanese ${ }^{1)}$. Cold syndrome has been believed to exist in many traditional medical theories in Korea, Iran, Greece, Arabia, Rome, India, etc ${ }^{23)}$. However, there is no definition of subjective coldness in Western medicine, and therefore it is not even recognized as a symptom or disease to be treated.

The lack of an objective outcome measure has prevented Kampo from being accepted as a global standard and an alternative for medical practitioners in the West. We have developed a computer-aided Kampo database referred to as Tokyo Women's Medical University Oriental Medicine Research Active Support System (TOMRASS), which accumulates patient-based evaluations covering a wide range of complaints, symptoms, and conditions ${ }^{4)-6}$.

We applied the TOMRASS database in order to evaluate the efficacy of a common Kampo agent, tokishigyakukagoshuyushokyoto in patients with cold syndrome. We believe this approach may provide a new paradigm that will allow Kampo medicine to be integrated into Western medicine.

\section{Susjects and methods \\ Patient eligibility}

Subjects were 181 Japanese patients attending Tokyo Women's Medical University Institute of Oriental Medicine (9 males and 172 females, mean age 43 years, age range 17-79 years) who complained of coldness without any apparent organic abnormalities at their first medical examination between September 2006 and September 2010. They were diagnosed as exhibiting eligible Sho, which can be translated into English as symptoms, signs, evidence or constitution, to be treated with the granulated extract product of tokishigyakukagoshuyushokyoto (Kracie Holdings, Ltd., Tokyo or Tsumura \& Co., Tokyo), 7.5 grams a day for a month.

The aim of logistic regression is to correctly pre- dict an outcome for individual cases without Kampo diagnosis. To verify the predictability using a model for the efficacy of treatment of coldness with tokishigyakukagoshuyushokyoto, additional 28 patients with coldness in the extremities at their first visit between October 2010 and April 2011 (one male and 27 females, mean age 42 years, age range 25-75 years) were selected for assessing an external validity. Sho was not taken into account for these newcomer patients. The Ethics Committee of Tokyo Women's Medical University School of Medicine approved all procedures, and informed consent was obtained from every patient.

\section{Evaluated items in TOMRASS database}

Patients were self-surveyed about their health using the Kampo questionnaire at their first visit and at every reexamination on a touchscreen computer without intervention by medical staff. After the patients had completed the questionnaire, medical doctors reviewed the completed questionnaire during a medical examination. The Kampo questionnaire was prepared with reference to the classical literature and guidelines of recognition through the basic Kampo concepts ; the three major substances of life (qi, blood, and fluid), the four essential dichotomies (yin-yang, hypofunction and hyperfunction, heat and cold, superficial and interior), and the five parenchymatous viscera (so-called heart, liver, kidney, spleen, and lung).

\section{Outcome measure}

Coldness was quantified by frequency and severity on a scale of 0 to 4 . Improvement of coldness was self-evaluated by patients at one month of treatment. To avoid ambiguity of outcome decision, 'effective' was defined as a decrease in both frequency and severity, while other cases were regarded as 'ineffective'.

Items are composed of age, body-mass index, 3 items on the mouth and tongue, an item on sphygmopalpation, 10 items on abdominal signs (Table 1), and 40 items on constitution and symptoms including feeling hot/cold (Table 2). Assessments of the items other than coldness were categorized as presence or absence.

\section{Statistical Analysis}

Paired t test, Chi-square test and Mann-Whitney $\mathrm{U}$ test were applied to detect significant associations 
Table 1 Details of medical examinations $(n=181)$

\begin{tabular}{|c|c|c|c|}
\hline & Effective & Ineffective & $p$ value \\
\hline \multicolumn{4}{|l|}{ General characteristics } \\
\hline Number of patients & 134 & 47 & - \\
\hline Age, median [range] & $43[17-79]$ & $45[20-75]$ & $0.88^{\dagger}$ \\
\hline Height $(\mathrm{cm})$, mean \pm SD & $159.2 \pm 6.3$ & $158.2 \pm 10.4$ & $0.57^{\mathrm{S}}$ \\
\hline Weight (kg) & $51.8 \pm 7.7$ & $51.5 \pm 9.5$ & $0.85^{\mathrm{S}}$ \\
\hline Body-mass index & $20.4 \pm 2.6$ & $21.0 \pm 7.2$ & $0.41^{\mathrm{s}}$ \\
\hline \multirow{2}{*}{$\begin{array}{ll}\text { Gender } & \text { Male } \\
& \text { Female }\end{array}$} & 4 & 5 & 0.052 \\
\hline & 130 & 42 & \\
\hline \multicolumn{4}{|c|}{ Region of coldness (multiple choice) } \\
\hline Extremities & 121 & 33 & $0.0017^{* *}$ \\
\hline Abdomen & 41 & 14 & 0.92 \\
\hline Back & 33 & 17 & 0.13 \\
\hline Whole body & 24 & 15 & 0.062 \\
\hline Femur & 1 & 1 & 0.45 \\
\hline \multicolumn{4}{|l|}{ Pulse signs (exclusive choice) } \\
\hline Deficiency & 51 & 16 & 0.73 \\
\hline Excess & 1 & 0 & 1.0 \\
\hline \multicolumn{4}{|c|}{ Signs of the tongue ( 3 items, multiple choice) } \\
\hline Teeth-marked tongue & 59 & 32 & $0.0064^{* *}$ \\
\hline White fur & 83 & 31 & 0.73 \\
\hline $\begin{array}{l}\text { Sublingual collateral } \\
\text { vessels }\end{array}$ & 77 & 34 & 0.083 \\
\hline \multicolumn{4}{|c|}{ Abdominal signs (10 items, multiple choice) } \\
\hline Tenderness in iliac region & 66 & 8 & $\underset{*}{<0.0001^{*}}$ \\
\hline $\begin{array}{l}\text { Lack of resistance of } \\
\text { lower abdomen }\end{array}$ & 26 & 16 & $0.047^{*}$ \\
\hline $\begin{array}{l}\text { Weakness of abdominal } \\
\text { strength }\end{array}$ & 35 & 17 & 0.20 \\
\hline $\begin{array}{l}\text { Pulsation at pit of } \\
\text { stomach }\end{array}$ & 72 & 19 & 0.13 \\
\hline Para-umbical tenderness & 71 & 20 & 0.24 \\
\hline Subchondrial resistance & 62 & 26 & 0.31 \\
\hline $\begin{array}{l}\text { Excessive strain of } \\
\text { abdominal muscles }\end{array}$ & 41 & 16 & 0.72 \\
\hline Epigastric registance & 40 & 15 & 0.85 \\
\hline $\begin{array}{l}\text { Abdominal fluid } \\
\text { congestion }\end{array}$ & 16 & 7 & 0.61 \\
\hline Recognition of linea alba & 11 & 5 & 0.57 \\
\hline
\end{tabular}

E: effective, I: ineffective. $\uparrow$ Mann-Whitney's U test,

$\$$ Student's $t$ test, chi-square test for categorical data. ${ }^{*} p<0.05,{ }^{* *} p<0.01$

between items and effectiveness of the treatment using SPSS Statistics ver.19 (IBM Corp., Armonk, NY, USA). Multiple logistic regression was performed to obtain an appropriate model for the prediction of treatment effect. Predictability was assessed by c-statistic derived from the logistic regression model. Significance was defined at $<0.05$.

\section{Results}

\section{Efficacy of tokishigyakukagoshuyushokyoto}

Among 181 patients with cold syndrome, the treatment was effective in 134 patients (74.0\%). There was no significant difference in patients' characteristics between the effective and ineffective groups (Table 1). The self-evaluation scales on both frequency and severity of coldness were improved from $3.2 \pm 0.7$ to $2.1 \pm 0.9(p<0.01)$ and from 3.1 \pm 0.7 to $2.2 \pm 0.9(p<0.01)$, respectively. The symptoms frequently accompanying coldness were stiff shoulders $(69.1 \%)$, general fatigue $(63.5 \%)$, chilly feeling (51.4\%), abdominal fullness (49.2\%), eyestrain (48.1\%), headache (47.5\%), lumbago (46.4\%), and listlessness (37.6\%).

\section{Seasonal influence on treatment for coldness}

Although the patients increased in winter and decreased in summer, the number of effective cases exceeded that of ineffective ones at all times of the year ( $p=0.0020$, Wilcoxon signed rank test). The probability of effectiveness was constant (75.1 \pm $10.1 \%$ ) without significant correlation to the month 
Table 2 Questionnaire for self-surveillance on physical constitution and accompanying symptoms (40 items, multiple answers, $\mathrm{n}=181$ )

\begin{tabular}{|c|c|c|c|c|}
\hline & uency $(\%)$ & $\mathrm{E}$ & I & $P$ value ${ }^{t}$ \\
\hline $\begin{array}{l}\text { Coexistence of coldness } \\
\text { and hot flush }\end{array}$ & $32(17.7)$ & 19 & 13 & $0.046^{*}$ \\
\hline Appetite loss & $13(7.2)$ & 5 & 8 & $0.0054^{* *}$ \\
\hline Sleepy feeling after meals & $57(31.5)$ & 35 & 22 & $0.011^{*}$ \\
\hline Upset stomach & $44(24.3)$ & 16 & 28 & $<0.0001^{* *}$ \\
\hline Heartburn & $21(11.6)$ & 7 & 14 & $<0.0001^{* *}$ \\
\hline Diarrhea & $23(12.7)$ & 10 & 13 & $0.0014^{* *}$ \\
\hline Depression & $45(24.9)$ & 25 & 20 & $0.0018^{* *}$ \\
\hline Mood swing & $21(11.6)$ & 9 & 12 & $0.0012^{* *}$ \\
\hline Eyestrain & $87(48.1)$ & 55 & 32 & $0.0021^{* *}$ \\
\hline Stiff shoulders & $125(69.1)$ & 90 & 35 & 0.46 \\
\hline General fatigue & $115(63.5)$ & 80 & 35 & 0.080 \\
\hline Chilly & $93(51.4)$ & 66 & 27 & 0.40 \\
\hline Abdominal fullness & $89(49.2)$ & 62 & 27 & 0.24 \\
\hline Headache & $86(47.5)$ & 63 & 23 & 0.87 \\
\hline Lumbago & $84(46.4)$ & 59 & 25 & 0.31 \\
\hline Listless & $68(37.6)$ & 49 & 19 & 0.73 \\
\hline $\begin{array}{l}\text { Upset stomach from over- } \\
\text { eating }\end{array}$ & $67(37.0)$ & 46 & 21 & 0.22 \\
\hline Paroxysmal sweating & $64(35.4)$ & 46 & 18 & 0.72 \\
\hline Constipation & $61(33.7)$ & 48 & 13 & 0.37 \\
\hline Dry skin & $60(33.1)$ & 42 & 18 & 0.47 \\
\hline Insomnia & $59(32.6)$ & 40 & 19 & 0.21 \\
\hline Abdominal pain & $53(29.3)$ & 41 & 12 & 0.58 \\
\hline Irritability & $43(23.8)$ & 30 & 13 & 0.55 \\
\hline Easily catching cold & $43(23.8)$ & 28 & 15 & 0.163 \\
\hline Edema & $42(23.2)$ & 29 & 13 & 0.43 \\
\hline Cramp in legs & $40(22.2)$ & 27 & 13 & 0.31 \\
\hline Vertigo & $39(21.5)$ & 33 & 6 & 0.10 \\
\hline Difficulty in waking up & $37(20.4)$ & 23 & 14 & 0.091 \\
\hline Chilblain & $36(19.9)$ & 30 & 6 & 0.20 \\
\hline Neuralgia & $32(17.7)$ & 21 & 11 & 0.27 \\
\hline Angry outburst & $31(17.1)$ & 21 & 10 & 0.38 \\
\hline Hot flush & 27 (14.9) & 16 & 11 & 0.093 \\
\hline Pollakiuria & $25(13.8)$ & 18 & 7 & 0.81 \\
\hline Hot feeling & $24(13.3)$ & 17 & 7 & 0.80 \\
\hline Unpleasant wind & $21(11.6)$ & 12 & 9 & 0.069 \\
\hline Fullness of the chest & $20(11.0)$ & 13 & 7 & 0.42 \\
\hline Palpitation & $20(11.0)$ & 12 & 8 & 0.17 \\
\hline Cold intolerance & $15(8.3)$ & 10 & 5 & 0.54 \\
\hline Belch & $14(7.7)$ & 9 & 5 & 0.36 \\
\hline Stuck feeling in throat & $6(3.3)$ & 3 & 3 & 0.18 \\
\hline
\end{tabular}

E: effective, I: ineffective, $£$ chi-square test. ${ }^{*} p<0.05,{ }^{* *} p<0.01$

of first visit ( $\mathrm{r}=-0.008, p=0.79$, Pearson's correlations).

\section{Univariate analysis}

The positively correlated variables were coldness in extremities and tenderness in iliac region, while the negatively correlated variables were teethmarked tongue, lack of resistance of lower abdominal region, coexistence of coldness and hot flushes, appetite loss, sleepy feeling after meals, upset stomach, heartburn, diarrhea, depression, mood swings and eyestrain (Tables 1 and 2).

\section{Discriminatory predictability of the efficacy of treatment}

Logistic regression analysis chose tenderness in iliac region $\left(x_{1}\right)$, upset stomach $\left(x_{2}\right)$ and depression $\left(x_{3}\right)$ to maximize the predictive accuracy of the model (Table 3). The discriminatory predictability of the efficacy of treatment was calculated as $84.4 \%$ (Table 3).

\section{Prospective verification of model adaptation}

A simple administration for the newcomer 28 patients without the complex Kampo diagnosis demonstrated that the sensitivity and specificity of the 
Table 3 Significant items in multiple logistic regression analysis and predictive accuracy of the model $(\mathrm{n}=181)$

\begin{tabular}{|c|c|c|c|c|c|c|}
\hline \multicolumn{2}{|l|}{ Item } & \multirow{2}{*}{$\frac{\text { Coefficient }}{1.76}$} & Odds ratio & \multicolumn{2}{|c|}{$95 \%$ CI of odds } & $P$ value \\
\hline \multicolumn{2}{|c|}{ Tenderness in iliac region $\left(x_{1}\right)$} & & 5.8 & \multicolumn{2}{|c|}{$2.15-15.6$} & $<0.0001$ \\
\hline \multicolumn{2}{|c|}{ Upset stomach $\left(x_{2}\right)$} & -2.35 & 0.096 & \multicolumn{2}{|c|}{$0.040-0.226$} & $<0.0001$ \\
\hline \multicolumn{2}{|l|}{ Depression $\left(x_{3}\right)$} & -1.26 & 0.28 & \multicolumn{2}{|c|}{$0.116-0.691$} & 0.0055 \\
\hline & \multicolumn{3}{|c|}{$\begin{array}{l}\text { Predicted efficacy }{ }^{\$} \text { of subjects } \\
(\mathrm{n}=181)\end{array}$} & \multicolumn{3}{|c|}{$\begin{array}{l}\text { Predicted efficacy }^{\$} \text { of new patients } \\
(\mathrm{n}=28)\end{array}$} \\
\hline Result of treatment & Effective & Ineffective & Correct & Effective & Ineffective & Correct \\
\hline Effective & 126 & 9 & $93.3 \%$ & 20 & 0 & $100.0 \%$ \\
\hline Ineffective & 19 & 27 & $58.7 \%$ & 5 & 3 & $37.5 \%$ \\
\hline Correct & $86.9 \%$ & $75.5 \%$ & - & $80.0 \%$ & $100.0 \%$ & - \\
\hline Predictive accuracy & & & $84.4 \%$ & & & $82.1 \%$ \\
\hline
\end{tabular}

$\$$ The probability of effectiveness, $\mathrm{P}(x)=1 /\{1+\exp (-y)\}$ where $y=1.65+1.76 x_{1}-2.35 x_{2}$ -

$1.26 x_{3} . \mathrm{P}(x)$ above 0.5 is taken as effective. $\uparrow$ The patients on their first visit between

October 2010 and April 2011 who were independent of the subjects enrolled in to make the

logistic regression model.

model were $100.0 \%$ and $37.5 \%$, respectively, and the predictive accuracy was $82.1 \%$ (Table 3 ).

\section{Discussion}

Kampo medicine, based on traditional Chinese herbal medicine, has been the backbone of Japanese medicine for four hundred years, and has its own system of disease cognition and its own healing philosophy, which have their roots in the Japanese way of thinking. Though Kampo is currently not the mainstream of medical treatment in Japan, which is based on Western medicine, ordinary Japanese people still give it a degree of credence, and Kampo formulae are covered by the National Health Insurance System (NHIS) in Japan. Therefore, it is important to examine the effect of Kampo medicine on disease entities understood in the framework of modern Western medicine ${ }^{7)}$.

$50-60 \%$ of patients visiting general gynecological clinics have reported complaints of coldness in Ja$\operatorname{pan}^{8) ~ 10)}$, and $40 \%$ and over of Chinese in good health have experienced coldness in extremities ${ }^{11}$. Miyazaki recently reported that this complaint worsened the health-related quality of life with a correlation to mental components in the short form health survey ${ }^{12)}$. Increased sensitivity of the body to cold, associated with low thyroid function and activation of sympathetic nerves in the extremities, are involved, though the mechanism remains unclear ${ }^{9 / 13(14)}$.

Tokishigyakukagoshuyushokyoto is decoction of 9 herbs: Angelicae Radix, Evodiae Fructus, Paeoniae Radix, Zizyphi Fructus, Cinnamoni Cortex, Asiasari Radix, Akebiae Aculis, Zingberis Rhizoma, and Glycyrrhizae Radix. The pharmaceutical-grade granulated extract products are covered by NHIS as high-quality, well-standardized, government-regulated versions of Kampo botanicals. They are usually given for hypofunctional constitution with yinsyndrome, headache and unusual coldness of the extremities $^{15)}$.

The computer-aided analysis of the patient-based database indicated that the effectiveness of the treatment could be predicted with the predictive accuracy and positive predictive value of $82.1 \%$ and $80.0 \%$ in 28 new patients, respectively, by the status of only three items among dozens of accompanying symptoms at the first visit even though Sho, the traditional and complicated Kampo's cognition, was not taken into account.

A holistic view based on the diverse peripheral symptoms and physical constitutions accompanying the chief complaint are very important for Kampo's cognitive paradigm to restore the balance between mental and physical activities. Placebo-controlled trials do not reflect the usual use of Kampo in actual practice. However, the basic concepts, such as yingyang, qi, five elements, five organs, Sho, etc., seem alien to Western practitioners. Therefore, it is important to establish a new method that would allow Western physicians and scientists to engage with Kampo's system of cognition and philosophy.

In conclusion, cold syndrome susceptible to tokishigyakukagoshuyushokyoto was very frequently accompanied by tenderness in iliac region, without upset stomach or depression. This modern Kampo cognition was obtained by using the computer-aided database of patient-based self-evaluation questionnaires system. 


\section{Disclosure Statement}

No competing financial interests exist.

\section{References}

1 ) Sato F, Matsushita S, Hyodo K et al. : Sex difference in peripheral arterial response to cold exposure. Circ J, 72, 1367-1372, 2008

2 ) Shin K, Kwak S, Lee J, Yi H : The effectiveness of hand acupuncture and moxibustion in decreasing pain and "coldness" in Korea women who have had hysterectomy : a pilot study. Appl Nurs Res, 19, 22-30, 2006

3 ) Shahabi S, Hassan Z, Mahdavi M et al. : Hot and Cold natures and some parameters of neuroendocrine and immune systems in traditional Iranian medicine : a preliminary study. J Altern Complement Med, 14, 147-156, 2008

4 ) Kimura Y, Sato H, Arai M, Iiyama K, Tanaka A. : Patientbased evaluation of Kampo therapy-Introduction of a clinical information database for patient-based assessmentKampo Med, 55, 337-342, 2004

5 ) Kimura Y, Takamatsu K, Fujii A et al. : Kampo therapy for premenstrual syndrome: efficacy of Kamishoyosan quantified using the second derivative of the fingertip photoplethysmogram. J Obstet Gynaecol Res, 33, 325-332, 2007

6 ) Ebiko K, Kikkawa M, Kimura Y, Sato H. : Clinical report 1 (Japan), acupuncture treatment for vertigo. Journal of Kampo, acupuncture and integrative medicine, 3, 9-12, 2008

7 ) Terasawa K. : Evidence-based Reconstruction of Kampo Medicine : Part-III-How Should Kampo be Evaluated? Evid Based Complement Alternat Med, 1, 219-222, 2004

8 ) Takatori A. : Assessment of diagnostic criterion of coldness in women with thermography (in Japanse). Acta Ob- stet Gynaecol Jpn, 44, 559-565, 1992

9 ) Ushiroyama T, Kajimoto Y, Sakuma K, Ueki M. : Assessment of chilly sensation in Japanese women with laser doppler fluxmetry and acceleration plethysmogram with respect to peripheral circulation. Bull Osaka Med Coll, 51, 76-84, 2005

10) Takeuchi T, Nakao M, Kohno M, Hatano M, Niimi M, Yano E. : Development of a questionnaire to assess 'Hie' symptoms using an evidence-based analysis. Environ Health Prev Med, 13, 338-344, 2008

11) Huo Y-h, Wang X-1, Li J et al. : Analysis of clinical manifestations of subhealth status in a medical college of Guangdong Province (in Chinese). Nan Fang Yi Ke Da Xue Xue Bao, 27, 448-449, 2007

12) Miyazaki J, Kuge H, Morisawa $T$ et al. : Behaviour factor in Hiesho (excessive sensitivity to cold symptoms), healthrelated QOL and BMI in male and female subjects who feel Hiesho (in Japanese). J Japan Soc Acupuncture and Moxibustion, 61, 174-181, 2011

13) Yakubo S, Yagi H, Kanmatsuse $\mathrm{K}$ et al. : Mechanism of improvement by Toki-shigyaku-ka-goshuyu-shokyo-to for abnormal cold feeling (in Japanese). J Trad Med, 14, 314315, 1997

14) Nagashima K, Yoda T, Yagishita T, Taniguchi A, Hosono $\mathrm{T}$, Kanosue K. : Thermal regulation and comfort during a mild-cold exposure in young Japanese women complaining of unusual coldness. J Appl Physiol, 92, 1029-1035, 2002

15) Kubota $T$, Inaki $K$, Homma $Y$ et al. : Diseases and Kampo. In : Satoh Y, Hanawa T, Arai M, Cyong J-C, Fukuzawa K, Mitani $\mathrm{K}$ et al., editors. Introduction to Kampo, Japanese traditional medicine, 1 ed, Tokyo : Elsevier Japan, p.118185,2005 